\title{
Study on Pt(Sn)/TiO 2 -C as Anodic Catalysts for Direct Ethanol Fuel Cell
}

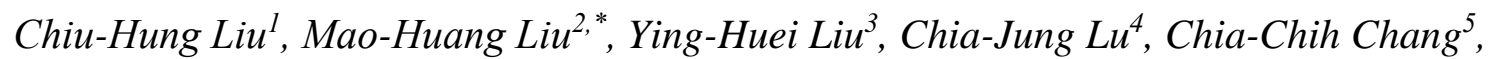 \\ Chih-Chia Wang ${ }^{3,6}$ and Chen-Bin Wang ${ }^{3,6, *}$ \\ ${ }^{1}$ Graduate School of National Defense Science, Chung Cheng Institute of Technology, National \\ Defense University, Taoyuan, Taiwan, ROC \\ ${ }^{2}$ Department of Chemistry, Fu-Jen Catholic University, New Taipei City, Taiwan, ROC \\ ${ }^{3}$ Department of Chemical and Materials Engineering, Chung Cheng Institute of Technology, National \\ Defense University, Taoyuan, Taiwan, ROC \\ ${ }^{4}$ Department of Chemistry, National Taiwan Normal University, Taipei, Taiwan, ROC \\ ${ }^{5}$ Department of Applied Chemistry, National Chiao Tung University, Hsinchu, Taiwan, ROC \\ ${ }^{6}$ System Engineering and Technology Program, National Chiao Tung University, Hsinchu, Taiwan, \\ ROC \\ *E-mail: $\underline{061355 @ m a i l . f j u . e d u . t w}$ and chenbinwang@gmail.com
}

doi: $10.20964 / 2020.12 .28$

Received: 31 July 2020 / Accepted: 25 September 2020 / Published: 31 October 2020

\begin{abstract}
This research concentrated on the use of a modified $\mathrm{Pt} / \mathrm{C}$ anodic catalyst with titania $\left(\mathrm{TiO}_{2}\right)$ and tin $(\mathrm{Sn})$ to enhance the utilization and efficiency of a direct ethanol fuel cell. The $\mathrm{TiO}_{2}$-doped active carbon support $\left(\mathrm{TiO}_{2}-\mathrm{C}\right)$ was prepared by the impregnation method. Then, using platinum chloride $\left(\mathrm{PtCl}_{4}\right)$ and tin (II) chloride dihydrate $\left(\mathrm{SnCl}_{2} \cdot 2 \mathrm{H}_{2} \mathrm{O}\right)$ as precursors, a $\mathrm{Pt}(\mathrm{Sn}) / \mathrm{TiO}_{2}-\mathrm{C}$ anodic catalyst was fabricated by the formic acid reduction method. Further, a series of $\mathrm{Pt}(\mathrm{Sn}) / \mathrm{TiO}_{2}-\mathrm{C}$ anodic catalysts were coated on carbon paper as working electrodes. Performance evaluations were executed by cyclic voltammetry (CV) and chronoamperometry for the ethanol electro-oxidation, and CO stripping voltammetry was performed in an acid solution at room temperature. Characterization of the series $\mathrm{Pt}(\mathrm{Sn}) / \mathrm{TiO}_{2}-\mathrm{C}$ catalysts displayed that all catalysts revealed uniform dispersion of platinum with a diameter around 3 - $6 \mathrm{~nm}$ and a high electrochemically active surface area. Apparently, the doping of $\mathrm{TiO}_{2}$ and $\mathrm{Sn}$ could disperse the active species, and lower the potential of the ethanol electro-oxidation to improve the ethanol oxidation reaction (EOR). In addition, the inclusion of $\mathrm{TiO}_{2}$ and $\mathrm{Sn}$ could promote $\mathrm{CO}$ stripping by the surface active $\mathrm{OH}_{\mathrm{ad}}$ sites and through the formation of a $\mathrm{PtSn}_{2}$ alloy at a lower oxidizing potential.
\end{abstract}

Keywords: $\mathrm{Pt}(\mathrm{Sn}) / \mathrm{TiO}_{2}-\mathrm{C}$ anodic catalyst; Electro-oxidation; Cyclic voltammetry.

\section{$\underline{\text { FULL TEXT }}$}


(C) 2020 The Authors. Published by ESG (www.electrochemsci.org). This article is an open access article distributed under the terms and conditions of the Creative Commons Attribution license (http://creativecommons.org/licenses/by/4.0/). 